\title{
The Role of Education in Irish Public Service Broadcasting
}

\author{
BERNIE GRUMMELL \\ University College Dublin
}

\begin{abstract}
The media's contribution to the creation of a healthy public sphere and civil society is the focus of public debate, especially in the light of concerns about the impact on them of the economic and political spheres. The media's ideal contribution to the development of a democratic society has traditionally been framed within the structures of the public service model of broadcasting, where education plays a crucial role. This article traces the evolution of education in Irish broadcasting, exploring the consequences for Irish democracy and civil life. It outlines how education's potential contribution has continually been shaped by the institutional demands of the political and economic systems, including the cultural nationalist ethos of early radio broadcasting, its role in the modernisation of Irish society, and the growth of commercialism and pluralist approaches. These trends had a formative influence on education's role in Irish broadcasting, and consequently on the civic and democratic lives of Irish citizens.
\end{abstract}

\section{Introduction}

The role of the media in the public sphere and civil society is the focus of public debate, prompted by concerns about the global impact of political and economic forces. The media is a vital component of the public sphere, facilitating the formation of public opinion and reasoned debate in society (Habermas 1987). It helps to develop a sense of critical reflectivity and civic engagement that is essential for a mature democratic society (Dahlgren 1995). These democratic and civic ideals lie at the heart of the contemporary public service broadcasting. Education has always been a central element in this public service system, forming an important aspect of the media's project to create and sustain a body of common knowledge, culture and community (Keane 1991; Scannell and Cardiff 1991).

The relationship between education, the media and democracy has been challenged by the growth of institutionalisation, globalisation and commercialism. Many commentators bemoan the fate of democracy and civil society in the light of these challenges (Putnam 2000; Lee 1997). Habermas (1987) describes a process of erosion of public and private life, as the system elements of power (the political 
sphere) and money (the economic sphere) encroach on the public sphere and lifeworld. In Ireland, this concern is set within the general debate about the impact of modernity, as the Celtic Tiger economy brings new cultural and political values of individualism, pluralism and consumerism to the fore (Kirby et al. 2002). The interest of media and educational systems increasingly focus on consumer targets and political interests rather than the maintenance of active citizenship.

The consequences for the public sphere and civil society are significant. The structures of democracy are being undermined, as the basis of common knowledge and critical abilities necessary for citizenship is endangered. The reality of the media's current role in society seems to lie far from the ideals of civic engagement and participation outlined above. Consequently, Verstraeten (1996: 359) calls for continued study of the 'institutional configuration' of the public sphere to identify the 'structural conditions necessary to form a democratic public sphere'. This article examines the role of education in Irish broadcasting and the consequences for the public sphere and civil society. Educational broadcasting is cast as the Cinderella of contemporary broadcasting, part of an old-fashioned public service ethos of enrichment and public responsibility. It is associated with the world of work, evoking connotations of concentration and diligent effort. Its current role in broadcasting is constrained as it is sidelined to the specialised genre of educational broadcasting, valued in principle but rarely supported in practical terms. This typecasting of education's role in broadcasting ignores its complex and varied role in public service broadcasting and democratic processes. Its formative role in the development of a public sense of civic engagement and active citizenship is neglected (Milner 2002). To understand how and why education's role in Irish broadcasting has developed in this manner, we need to look to the past.

\section{Origins of Irish broadcasting - education in the radio era}

Radio Eireann was expected not merely to reflect every aspect of national activity but to create activities that did not yet exist. It was expected to revive the speaking of Irish; to foster a taste for classical music; to revive Irish traditional music; to keep people on farms; to sell goods and services of all kinds, from sausages to sweep tickets; to provide a living and a career for writers and musicians; to reunite the Irish people at home with those overseas; to end Partition. All this in addition to broadcasting's normal duty to inform, educate, and entertain. (Gorham 1967: 221)

Irish broadcasting developed as a form of public service broadcasting, facilitating and enabling a common knowledge, culture and identity amongst the Irish public in the context of the newly established Irish Free State. Bell (1995: 80) outlines how a 'new notion of a nation - a Catholic Gaelic nation - had to be invented as part of a national popular program to secure bourgeois hegemony in the new state'. Broadcasting was to play a key role in securing the social and cultural hegemony of the Irish nation. Education was given a central position within this project, 
helping to inform and enrich the cultural life of the nation. Like the BBC, Irish broadcasting began with the prescriptive outlook of what the public should 'demand'. ' An educational ethos of enrichment and improvement permeated all of its programming, albeit with a specific Irish emphasis.

Education's contribution was set within an 'educative' approach in two areas of radio - cultural programmes on Irish music, traditions, and language, and in the more practical form of educational talks on topics like agriculture, gardening and history (Cathcart 1984: 42). This educative category fits into the general ethos of the public service model, defined by Groombridge (in Tight 1983: 4-5) as the 'intention to shape attitudes and mould consciousness'. Formal educational broadcasting emerged during the 1930s, with the introduction of after-school programmes. This series gained 'the blessing of the Department of Education, although they had no direct connection with the school syllabus' (Gorham 1967: 101). It marked the first appearance of education as a programme genre in its own right on the Irish airwaves, and was an important indictor of the future role and difficulties that Irish educational broadcasting was to face. Education was associated with the vulnerable sectors of the population (especially women and children) and a 'women's organiser' was appointed to deal with this type of programming (ibid.). The creation of this post reflected the Catholic view of women as natural carers of the Irish family. Education's role in broadcasting was to assist in the development of an Irish civil society within the Catholic-based ideology of cultural protectionism and Irish nationalism (Bell 1995). This positioning of education would seem to indicate that education would gain a high status in Irish broadcasting, buttressed by state and institutional support.

In reality, a tone of reluctance was evident in the Irish state's attitude towards public service broadcasting, and more specifically education's role in broadcasting. The Department of Education was initially sceptical about the contribution of broadcasting to its services and maintained - in the case of Irish language programmes in the 1940s - 'that the educational results would not be commensurate with the cost, time and effort involved' (Gorham 1967: 164). A similar rationale was given for the rejection of the Irish National Teachers Organisation's support for the use of radio and film as educational tools in schools in 1949. Such reluctance encapsulated the Irish state's attitude towards broadcasting during this time. This discrepancy between the endorsement of education's importance in the public service philosophy and its practice in Irish broadcasting can be traced back to the fact that economic and political factors often took precedence over cultural and social factors. The weak economic situation of the new nation had necessitated the adoption of commercial values. A policy of interventionism was introduced in the 1920s, followed by economic protectionism in the 1930s and 1940s in an attempt to consolidate Irish independence and industry (Bell 1995). Broadcasting's main purpose was still to be a public servant, albeit one that should pay its own wages. This economic imperative deflected attention away from the cultural and public ideals that Irish broadcasting was promoting. 
The emphasis on economic viability also tended to distract attention from the underlying issue of power. The 'Irish State's traditional reluctance to provide adequate finance for broadcasting, coupled with its perpetual desire to control it' has been a consistent feature of Irish broadcasting (Bell 1984: 40). The cultural and nationalist ideals of the public service philosophy floundered as Irish broadcasting became intertwined with political power and goals. Its educational role was shaped by this complex interplay between philosophical ideals and the practical demands of political and economic spheres. By the end of the 1950s, the political project of cultural protectionism was flagging. The 1960s brought a wave of change that affected all aspects of Irish society. The Catholic, Gaelic nation that had been established by this stage was facing its greatest challenge with the growth of modernity. The alliance between the state and the Catholic Church was weakening and soon the state assumed responsibility for many of the social services, including education, which the Church had previously controlled.

These changes had important consequences for Irish broadcasting and the educational genre. Public service broadcasting had to develop a new ethos that would fit into the spirit of this modern era. The adoption of a modernisation discourse provided a more secure basis to legitimate the role of education in Irish public service broadcasting. Its success was reflected in the increasing number of educational productions made by Radio Eireann and supported by the Department of Education over the next few years (including Irish language plays for schools and the Tales Out of School series in the mid 1950s). Adult educational programming made its first formal appearance - as a programme genre distinct from the educative nature of other broadcasts - in 1953 with the Thomas Davis Lecture series. The formalisation of education's role in Irish broadcasting continued during the 1950s with the re-organisation of departmental structures within Radio Éireann, leaving education as the responsibility of the new children's programming department. ${ }^{2}$

Despite this activity on their part, the Department of Education was still not entirely persuaded by the idea of educational broadcasting. They saw its role as one of additional support rather than an educational activity in its own right. Educational radio had achieved the important milestone of gaining institutional approval, even if this was restricted to after-school hours. This endorsement gave educational broadcasting an operational basis that would lay the foundations for its expansion during the 1960s and 1970s. It also indicated the problems that were to face educational broadcasting during the 1960s, as it attempted to cast off the association with cultural nationalism and carve a place for itself in a modern era. It had become intertwined with the institutional demands and framing of the educational system rather than maintaining a clear focus on the needs of the Irish civil society and democracy. Consequently, the institutionalisation of education's role in Irish broadcasting seemed to push it down a path where it became a servant of the system rather than a public servant of the people - the encroachment by the system elements of money and power that Habermas (1987) outlined. 


\section{The television era, modernisation and the expansion of education's role}

Television was introduced to Ireland at the end of 1961 as a central part of the modernisation of Irish culture and society (O'Broin 1986). While the cultural basis and legitimation of education's role in public service broadcasting was changing, economic and political features continued to shape its role in Irish broadcasting. The development of Irish television was set within the context of the Irish government's deliberations between the need for political control and public service on the one hand, and the desire to make the service financially viable on the other (positioned as a struggle between political and economic rationales). The fiscal interest was prompted by the decline in the Irish economy since the mid-1950s. A complete overhaul of Irish society was proposed to develop a modern, capitalist country. ${ }^{3}$ Television was a core part of this 'progressive nationalism' plan, facilitating a modernist outlook and culture (Bell 1995: 81).

These plans were set within the general concern about the public and cultural impact of television. The extent of television's influence over people was being questioned - positively in the case of developing a sense of national and cultural identity, and negatively in terms of the 'grave risk of cultural osmosis' (Doolan et al. 1969: 11). Broadcasters were held responsible for the effects of broadcasting and had to be cautious - 'until there is clear and unmistakable proof to the contrary, they must assume that broadcasting is an important force in influencing the values and standards of society' (RTÉ 1971: 7). This paternalistic discourse negated any sense of power or responsibility of its audience. It positioned the administrative and expert driven structures of institutions like broadcasting and education as responsible for the effects of broadcasting. Unquestioned in this approach was the role of the audience - any sense of activity as television viewers, let alone the rights and responsibilities associated with citizenship - were absent. In Habermas's (1987) terms, it was evidence of the colonisation of the lifeworld.

The views expressed by Radio Telef"s Éireann (RTÉ) were in line with the Reithian public service philosophy, according to which broadcasters had an important public role to fulfil - the responsibility for guiding the development of its citizens. This was not seen as a politically neutral task focusing on a universal notion of the public good (Garnham 1993), but was set within the cultural nationalist framework that dominated Irish politics ${ }^{4}$ RTÉ provided programming that:

would reflect traditional Irish values, and would recognise Radio Éireann's responsibility as a public service concerned with cultural and educational matters as well as with the provision of news and entertainment. (Broadcasting Authority Annual Report, 1960-1 in Fisher 1978: 31)

A contradiction rapidly emerged (and was already evident from radio) between these public service ideals and how they would be expressed in the practicalities of Irish broadcasting. While cultural and educational programmes were viewed as exemplars of public service broadcasting, they were not seen as viable as a means of capturing popular interest or in terms of commercial feasibility. Education was 
still placed squarely within the cultural arena with little hope of commercial success, and hence control over its development was denied. The financial requirement imposed by the government introduced a commercial aspect that often conflicted with the democratic and cultural values underpinning public service broadcasting. It was an example of the government's eternal hope that broadcasting could fulfil several options. RTÉ was to manage itself (through the Authority) while still bowing to the overall command of the ministry. It was to maintain its public service ideals but in a spirit of commercial viability. It was to modernise Irish culture while still protecting and developing our national culture. In short, it was to be all things to all people.

Roseingrave (1983: 10) identified the need to define and protect Irish national culture as one of the central dilemmas facing the RTÉ Authority. What this national culture was, and how RTÉ was to set about developing it, was not clear. On the one hand, it could be defined narrowly as the Gaelic, Catholic culture that Bell (1995) outlined. A more open approach was taken by RTÉ, who defined it in terms of its general contribution to national identity. It still maintained the moral educative force of public service broadcasting: 'the duty of endeavouring to extend the horizons, enlarge the understanding and widen the appreciation of the broadcasting audience' (1971 RTÉ Authority cited in Fisher 1978: 52). This latter view promoted an image of broadcasting as an empowering force in the development of the civil society and the education of its citizens. Given these aims, it would appear that cultural and educational broadcasting would top the list of broadcasting priorities. Problems arose, however, about how these ideals would be put into practice.

The position of educational broadcasting seemed initially secure, with generous funding of children's and educational programming during the first few years of television. These programmes were welcomed by the Department of Education and the Council of Education in the wake of concern about the impact of television on the youth. The Department of Education also funded grants for the acquisition of television sets in secondary schools (as they had done earlier with radio). Their previous scepticism about the educational potential of broadcasting seemed to disappear as they agreed to finance the production of school programmes. ${ }^{5}$ This change of opinion appeared to be prompted by the modernisation drive of the Irish state in the 1960 s, especially the reforms of the educational system and its demand for teacher and student training in the new maths and science curriculum. This was followed in 1965 by the Telef "s Feirme series, financed by the Department of Agriculture as part of the modernisation of Irish agriculture. Both the Telef" $s$ Feirme and Telef"s Scoile series reflected the changes in the state's attitude towards broadcasting, as they gained a utilitarian interest in broadcasting when it could provide a centralised way of rapidly communicating new information and techniques.

This utilitarian interest can be linked back to the notion of economic viability in this case, the modernisation of Irish society seemed to provide a coherent 
legitimation for educational broadcasting that the cultural nationalist discourse of the former era had lacked. O Riágain (cited in Hourigan 1998: 57) describes the government's attitude 'as one of benign neglect with questions of national identity and language revival being set aside in favour of the achievement of other economic and social goals'. Although these cultural goals were still enshrined in public service broadcasting policy, in practice they were fading into the background as other aims took precedence in this era of modernisation. This new legitimacy was based on the logic of the economic and political system and their immediate strategies (i.e. the modernisation of Irish society) rather than the long-term democratic and civic goals of public service broadcasting.

The immediacy of this modernisation project resulted in a general lack of reflection about the changing role of broadcasting in Irish society, especially in terms of its public service aspirations. This neglect was starkly evident in the absence of policy-making on the role of education in Irish broadcasting during this time. Committees were established, but given little power or guidance to act - for example, the Advisory Committee on Educational Broadcasting established in 1964 had no fixed terms of reference and remained in an advisory capacity until 1976 (RTÉ 1979). They were asked 'to examine the question of educational broadcasting and how, within [RTÉ's] resources, it can be best developed' 6 The voluntary nature of this group reflected its lack of actual power - it could advise, but not act on any of its recommendations. The Department of Education retained full control over the coverage of education on Irish television, in the shape of the Telef"s Scoile series. RTÉ's role was restricted to the production and broadcast of programmes. Material from the school syllabus was translated directly from its printed form to television, presenting classroom teaching on television screens. The contribution of education to Irish broadcasting was to remain within these boundaries established by educational and broadcasting institutions, rather than developing other ways to achieve the civic and democratic objectives set by its public service basis.

Internal restructuring within RTÉ that occurred during this modernisation process included the extension of the educational programmes department's brief to encompass adult education. Education was formally separated from the children's programming department in 1969 and established as an independent department headed by Maev Conway-Piskorski. Despite these structural changes, no additional funding was made available for the new area of adult education. The new department's main activity still rested in the Telef"s Scoile series. However, adult educational programmes gradually began to feature in the television schedules. They centred on a particular type of adult education aimed at a general audience interested in enrichment and further education. Television series like Dressmaking with Ann Ladbury, the BBC's Medicine Today for medical staff, and the philosophical series Makers of Modern Man give a typical picture of adult educational television in the 1970s. These programmes were a mixture of acquired and home-produced programming. The home-produced programmes were funded 
by RTE and the Department of Education and were sporadic in their appearance because of the lack of consistent funding. ${ }^{7}$ This situation was indicative of the wider problem facing RTÉ. It continued to have very little power because of state control over the licence fee and the amount of advertising allowed. A consultants' report in 1976 examined the financial efficiency of RTÉ and concluded that it was efficiently run, but due to rising costs either needed more financing or would have to cut costs (Fisher 1978: 77).

The lack of funding for educational broadcasting was an issue that was explicitly addressed by the Broadcasting Review Committee (1974). It highlighted the institutional struggle that educational broadcasting found itself immersed within. RTÉ claimed that its educational function was 'in the provision of programmes which are generally or indirectly educative', contending that formal educational programming should be the responsibility of those directly responsibility for public education (1974: 106). The Department of Education, on the other hand, argued that RTÉ 'should be required to accept full responsibility for schools programmes as part of its normal function' (1974: 107). There was no obvious solution to this debate over political responsibility, with the Broadcasting Review Committee concluding that 'the present arrangement whereby the Department of Education pays for the programmes produced for and broadcast to schools should continue' (ibid.). More importantly, this highlighted the lack of support for educational broadcasting that existed by this stage, with RTÉ and the Department of Education both attempting to use political reasoning to avoid economic responsibility. The urgent modernisation demands that had sustained educational broadcasting during the previous decade had vanished.

The mid-1970s marked the end of the world post-war boom with economic growth slowing and public expense growing. This was allied with the beginning of the international economic recession that characterised the early 1980s. As a result, the Irish economy had to cope with rising inflation rates and high unemployment levels. Like other state sponsored institutions, RTÉ suffered from a lack of investment that was exacerbated by the rising production costs of broadcasting. The dangers of its dependence on the Department of Education for educational funding was starkly demonstrated by the withdrawal of funding for the Telef" $s$ Scoile series in 1975. The rationale behind this decision seemed to lie in the economic background and the lack of necessity for school programming now that the curriculum had been modernised. The other crucial factor was the abolition of fees in post-primary schools in 1967, and the resultant changing demographic structure of the school population (Clancy 1995). This led to the near-oblivion of the genre of educational programming for the next decade, with programming consisting of repeat Telef" $s$ Scoile broadcasts.

Policy formation for educational broadcasting continued unabated, however, with the Educational Media Review Committee appointed in 1975 'to examine the question of audio-visual resources in education, and to make recommendations to the Department as to how such resources could be used most effectively and 
economically in the future' (RTÉ 1975: 1). A change can be noted in its remit to a more commercial tone with the emphasis on economic viability rather than the public service basis and advisory nature of earlier committees. The committee was terminated after a year, as changes in the Broadcasting Act moved responsibility for such committees to the RTÉ Authority.

The Authority established an Advisory Committee on Educational Broadcasting in 1977. Its remit focused on the 'financial and other constraints within which the Authority is obliged to operate' (RTÉ 1979: 1). Its report for the Authority presented a short-term view of the immediate opportunities available to RTÉ. It outlined the fundamental weakness facing educational broadcasting in Ireland - the absence of long-term planning and commitment, highlighting the continued lack of political and economic support for this area. In the area of adult education, they identified the main task of adult education broadcasting as a 'continuous and growing need to assist in the development of an informed democracy and to stimulate full participation in its institutions' (RTÉ 1979: 27). The work of these committees drew attention to the difficult position that educational broadcasting had found itself in. Education's role in society was perceived as vital in the face of the demands of the changing industrial world. This report had highlighted education's central role in developing the civic knowledge and participation that Irish democracy needed. However, broadcasting faced the seemingly insurmountable barrier of securing funding and support as the 1980s world recession loomed. The public service role of broadcasters like RTÉ seemed in serious danger because of the economic and political restrictions placed on it.

\section{The rise of commercialism - consequences for education's role in broadcasting}

The solution to the precarious financial position in which RTÉ, and the Irish economy, found itself by the middle of 1980 s was sought in free-market capitalism. In line with global trends, the Irish government began to deregulate national communications and broadcasting. RTÉ lost its monopoly position in Irish broadcasting in the 1988 Radio and Television Act. RTÉ's advertising income was capped to allow more market space for the newly established commercial stations in the 1990 Broadcasting Act. The commercial swing in government thinking can be seen in their intention of 'ensuring that Irish broadcasting becomes a growth industry, bringing new investment and higher productivity into Irish broadcasting, creating new secure employment in the sector, providing choice to the consumer' (Minister for Justice and Communications [1990], cited in Truetzschler 1991: 33).

This privatisation programme resulted in what Bell described as an ideological crisis for the Irish state, as the governing Fianna Fáil party tried to maintain a 'discourse on national sovereignty while abandoning the corporatist commitments that have in the past materially underpinned it' (1984: 85). This was combined with the worsening economic situation and a series of financial scandals that lead to the downfall of this government. The new governing parties (a coalition of Fine 
Gael with smaller social democratic parties) took a different line and embraced a revisionist pan-European and social democratic ideology that was supported by the secular middle class intelligentsia of 'academics, policy advisors and media experts' (Doak 1998: 29). This ideology was worked in opposition to the older cultural nationalist and modernising discourses, as many of the previous policies on broadcasting were reversed, including the advertising restrictions on RTÉ.

Government strategies were based on a social democratic rationale rather than the former stance of 'national self-determination' (Watson 1996: 3). The ensuing social democratic and labour coalition government continued this approach, developing a pluralist and minority rights discourse that was to have a major influence on broadcasting. This new role of broadcasting was described rather flamboyantly in the Green Paper on Broadcasting (1995: 131) as the:

motor of modernisation, cultural innovation, social transformation, even democratisation. It can cultivate a healthy public sphere in which national self-confidence flourishes...[and] critically interrogate a nation's history, culture and identity.

Broadcasting was to be all things to all men, albeit in different terms from Gorham's more prosaic analogy of Radio Éireann's perceived objectives (see opening quotation). Irish broadcasting's objectives were expressed in philosophical and sociological terms, reflecting the prevalent state discourse - in its official publications at least - of modernisation, civic development and social democracy. This seemed to indicate a new era when educational broadcasting could rise to the forefront, legitimated by its potential contribution to the development of critical reflectivity in the public sphere. However, this potential contribution has to be set within the changing economic and political context of this era. The rise of global and commercial discourses marked an important transition as broadcasting policymaking across Europe moved from a cultural to an industrial basis (McQuail and Suine 1986). Broadcasting was increasingly placed in the context of a global marketplace, reflecting the competitive nature of broadcasting as national monopolies ended and commercialisation increased. The centralised and hierarchical structures of broadcasters like RTÉ found it difficult to legitimate their public service stance in an era dominated by the demand for profitability and rationalisation, despite this evidence of state support in the Green Paper (Horgan 2001: 159).

The changing rationale being adopted by public service broadcasting was seen clearly in the example of Irish language broadcasting. Several attempts had been made in the past to establish Irish language broadcasting in the light of its important role in Irish culture and national identity (Watson 2003; Hourigan 1998). Its status in broadcasting was similar to that of education, high in symbolic value but low in terms of its practices in the everyday life of media producers and the audience ( $O$ Riágain and $O$ Gliasáin 1994). Irish language programming faced the same crisis as educational broadcasting, unable to gain funding for an area of programming that was strongly supported in public service policies. The background to this debate had changed by the early 1990s, with Watson (2003) 
identifying its origins in the social democratic government attempting to reconstruct a sense of national identity based on an amalgamation of democratic and commercial values. It promoted a new discourse of minority rights and specialised audience targeting that enabled the successful establishment of an Irish language television station and other audio-visual industries during the 1990s. Irish language broadcasting no longer had to justify itself on nationalist or commercial grounds as it could now legitimate itself within a minority rights framework. Educational broadcasting adopted a similar logic during the 1990s as outlined below.

The economic background to educational broadcasting's adoption of a minority rights rationale has to be examined first to understand how this transition occurred. Commercial elements are evident in all areas of public service broadcasting today, including popular entertainment programming, independent commissioned productions and other cost-cutting and restructuring strategies. Its critics have questioned the success of this approach, arguing that it is in direct opposition to the public service rationale (McQuail 1992; Rowland and Treacy 1990). Others see it as another stage in the evolution of broadcasting, as public service broadcasting moves to a new stage of 'managed monopoly' (Bell and Meehan 1989 in Bell 1995:74). Regardless of these evaluations, what is evident is that the balancing act between public service and commercial elements is fraught with tension. The struggle to justify the democratic and civic ideals of public service broadcasting in political and economic terms was equally difficult. RTÉ balanced these demands by appealing to its public service basis as the protectors of public interest in the broadcast field. The basis of this public interest had moved from a 'majority rule' of traditional public service broadcasting to a legitimation based on the provision of equal access to minority interests ignored by commercial broadcasters. The development and maintenance of a democratic society is still placed at the core of public service broadcasting's value system, but it is an ambition that has to be qualified within the economic and political demands placed on broadcasting.

This growing influence of a commercial rationale was particularly relevant for educational broadcasting which had been conspicuous by its absence during the 1980s. The golden era of educational broadcasting in Ireland seemed to end with the abandonment of the Telef"s Scoile series in the mid 1970s. The difficulties that Ireland and RTÉ had found themselves in during the 1980s had profound consequences for educational broadcasting. The translation of education's role from the ideals of the public service philosophy to the practices of broadcasting had always been problematic. It now seemed impossible, as the very structures of public service broadcasting that had supported it were undermined. The status of education within the older civilising and enrichment ethos did not seem to have a place in the new consumer-orientated world. The vagaries of inconsistent financial and structural support had hit home with a near complete halt in funding for educational programmes.

RTÉ had always had difficulties in identifying what role education should play in its services, and by the end of the 1980 s it sidestepped the issue by defining all 
broadcasting as educational 'since it conveys experience of various kinds' (1989: 21). While this understanding of education as an 'educative' function of broadcasting may have fitted in with adult educational discourse of lifelong learning, it did not help in the struggle to maintain an educational presence in Irish broadcasting. The genre of formal educational broadcasting largely vanished from Irish broadcasting - in particular television screens - during this decade. Programming consisted of repeat broadcasts from previous decades and some acquired programming, centring on the categories of socio-cultural and leisure programmes. ${ }^{8}$

\section{Lifelong learning and the re-shaping of education's role in broadcasting}

This apparent demise of the formal educational genre and the growth of entertainment programming disguised the beginning of a new era for education in Irish broadcasting. Innovations in the educational field began to emerge on Irish radio during the 1980s that would lead the way into the future. Understandings of education were being refined, discarding the institutional notion of a didactic education that finished with the school system. It was replaced by the idea of a lifelong process of learning 'as a dynamic and analytical approach to living' in an era of rapid social and economic change (Fisher 1978: 3). Importantly, this type of education promoted the critical reflectivity and civil abilities essential for civil society and democratic processes.

Two different strands of adult education became evident in this new framework. Firstly, lifelong learning programmes like Monday at Five, Access, New Wave and the Readin' and Writin' radio literacy programmes explored popular social and educational issues and enabled audience participation and empowerment - a necessary element in the development of civil society. Secondly, academic education was beginning to make its presence felt again, with experimentation in the field of distance education. RTÉ was involved in the early efforts to establish a broadcast aspect to the Irish distance education by the National Institute for Higher Education (NIHE), Dublin (now National Distance Education Centre). The broadcast aspect was later dropped, as the service concentrated on print materials and tutorials. Distance education remained accessible to the Irish public, however, through the Open University courses broadcast by the BBC. The focus on distance education continued in 1985, when RTÉ broadcast a BBC/Open University television series, Adults Learning, as part of a course run in association with the Centre for Adult and Community Development. RTÉ also produced a radio series to correspond with this course. This series marked the formalisation of adult education on Irish television with the provision of certification for learners.

These areas of adult education programming were to mark the lifeline that Irish educational broadcasting would take as its traditional public service role was eroded. Irish broadcasting's rationale was shifting from the general cultural and social needs of the nation to focus on the needs of citizens as workers and consumers in a global information society. Ideally, this would engage people in a 
lifelong and empowering process of learning that would contribute to societal levels of civic engagement and participation. However, Hughes and Tight (1995) argue that the contradictory demands between economic and civic aims are evident of the mythic nature of this lifelong learning discourse. On the surface, lifelong learning promotes the idea that the individual is responsible for their learning. However, when this emphasis on individualism is set within the economic and political structures of advanced capitalism, a dangerous alliance is created. It places responsibility for education squarely on the individual, allowing the state to abandon education to the 'blind workings of the market' (Jonathan 1990: 22). Education becomes a controlling - rather than an emancipatory - force that incorporates people into the existing social and economic order (Inglis 1997).

RTÉ attempted to embrace some commercial strategies by developing specialised schedules of educational programmes in the shape of the Ollscoil schedule in 1990 , followed by the Opening Learning schedule in 1993. These schedules consisted of broadcasts during the morning time on a variety of topics for pre-school, school and adult education. They demonstrated a consumer-orientated approach towards education by targeting specialised audience groupings. Programmes included in these schedules were developed by the new production strategies that had begun to emerge in the 1980s. The older approach of in-house production within RTÉ was replaced by the more commercial policies of independent commissioning, programme acquisitions, and partnership deals with outside production companies. This trend was initiated in the early 1990s in the shape of associated productions with independent producers like AVC (Audio Visual Centre ${ }^{9}$ ), and educational bodies like AONTAS (National Association of Adult Education) and NALA (National Adult Literacy Agency). This strategy enabled the production of 'high volume/low cost independent productions funded through a combination of acquisition fees and access to production studios provided by RTÉ' (MacMahon 1997: 6). Educational programming also entered into new areas as it attempted to develop interactive and participative models of production (including interactive learning projects and the Right To Learn and LearnNet series in the 1990s). These policies heralded a new ethos in educational production as it changed to the commercial principles of cost efficiency (relative to the costs of mainstream production techniques), the use of new media technology, the targeting of specific audience groups, and the development of new content areas.

The adoption of these commercial strategies was fraught with tension as the recent restructuring of RTÉ's educational services illustrated. This led to the apparent lapse of mainstream educational broadcasting in the early 2000s as the Head Editor of Educational Programmes was moved from the television services to work on the plans for an educational channel in the proposed digital services. This latter work focused on the introduction of media technology to schools and the development of a digital learning partnership between RTÉ and the Department of Education and Science. With the cancellation of RTÉ's planned digital services and the proposed legislative changes to Irish and European broadcasting, however, 
its future is unclear.

During the same time, RTÉ has implemented a charter of its public service remit in line with the recommendations of the 2002 Forum on Broadcasting. Education is specifically identified as a form of public service programming that should be encouraged, along with Irish language, cultural and children's programming. As a consequence of these changes, the Editor of Educational Programmes, John MacMahon, was moved back to television services into a newly established departmental structure of 'Irish language, Multiculturalism and Education'. He returns to a changed television landscape, as the Open Learning schedule of educational programming that he had initiated in the 1990s has vanished, and the only formal educational series that exists on the television schedule in the 2003 season are the foreign language programmes and the Read Write Now literacy series. The formal genre of educational broadcasting seems to have vanished once again by a sleight of hand, despite its adoption of commercial features.

The other categories of socio-cultural and educative programmes that had formerly been treasured in public service broadcasting are now left to the individual efforts of other producers. Their public service contribution to the development of social and cultural capabilities of the audience is largely forgotten. As the civic rationale that had underpinned education's role in traditional public service broadcasting is neglected, education is increasingly restricted to a narrow role as a specialised genre of academic education or as a diffused broadcast function that can be slotted into popular genres. This latter process is reflected in the continued development of what Tunstall (1993) describes as 'edutainment' programmes (similar to the hybrid category of infotainment programming). These new genres blend education and information into an entertainment mix, giving them a fresh appeal in the popular context of broadcasting's entertainment formats. This change is seen in the features genre, with the growing popularity of what were formerly considered educational programmes (including cookery, DIY and gardening programmes). It is also seen in the presentation of documentary and historical programmes within a narrative framework of a murder mystery or an archaeological thriller, and in dramatic storylines that highlight particular social issues (like literacy, racism, crime). This re-presentation of educational material in an entertaining format can be viewed positively as an indictor of the continued survival of education in public service broadcasting - and perhaps a strange and unexpected mutation of the adult education principle of a lifelong learning that is integrated into people's lifestyles. However, as this analysis of educational broadcasting in Ireland reveals, it also raises the spectre of questions that are often neglected, centring on the issue of the influence of economic and political power over broadcasting and civic life. 


\section{Conclusion}

The struggle of educational broadcasting highlights important issues for the role of public service broadcasting in Ireland. Educational broadcasting had for so long been the poor relation of Irish broadcasting - high enough in status but low in priorities. Its civic-minded aspirations of developing the social and cultural abilities of its citizens floundered in the face of political and economic restraints. It has been intertwined over the decades with the political projects of cultural and progressive nationalism, modernisation and minority interests, resulting in broadcasting becoming an 'instrument of public policy' for political ends as much as for the public good (Chubb 1982: 76). Education's role in Irish broadcasting has been continually bound up with these institutional demands of the political sphere because of its dependence on this sphere for economic funding and institutional recognition. The lack of clarity over education's role in the public service discourse resulted in a reluctance to address the practical needs of this form of broadcasting, enabling RTÉ and the state to support it in notional terms but to shy away from the practical issues of funding and policy-making. This is a problem that has faced educational broadcasting for many years as the 1974 Broadcasting Review Committee report highlighted - it is a core principle of broadcasting that has continuously lacked the direct support of the relevant institutional structures as RTÉ and the Department of Education juggle responsibility for its development.

Education has currently managed to carve out a precarious place for itself in Irish broadcasting, built out of the remnants of the occasional support that it has gained. It currently justifies attention based on the new discourses of pluralism, minority rights and the knowledge society project. However, the economic and politically motivated nature of these discourses neglects educational broadcasting's contribution to the public sphere and civil society. This highlights the continual lack of attention that has been paid to the public service and civic role of broadcasting. As Lee (1997: 10) points out, 'the primary purpose of public service broadcasting ought to be to provide a forum conducive to fostering a tradition of vigorous, open, pluralistic debate.' Education has a key role to play in the development of critical reflectivity and rational-critical debate, but its' role can only be clearly developed if political and economic systems are sensitive to this form of education, in broadcasting and other spheres. The contribution of education and broadcasting can only be developed within a wider political and social structure that promotes a mature civil society where 'the structures of power can be renovated and citizens control the uses of power' (Höyrinen-Alestalo 2001: 211). 


\section{Notes}

1. BBC described its role in 1935 as 'providing a service somewhat ahead of what the public would demand were it possible for such a demand to be made articulate and intelligible' (Briggs, 1965: 482).

2. These changes occurred as the former head of women's and children's programming Kathleen Roody retired. She was the first person in charge of educational programming in Ireland, having taken up the position as women's organiser in 1926. Seamus Kavanagh, followed by Maev Conway (later known by her married name Maev Conway-Piskorski) became the new head of children's programming (Clarke, 1986; Gorham, 1967).

3. Roseingrave (1983:10) outlines the key economic, social, religious and demographic factors including the Whitaker plan for economic development; modernisation of the education curriculum; growth of urbanisation and the expansion of the welfare state.

4. The station was first called Telef"s Éreann (with Radio Eireann covering radio services) but was commonly known as RTÉ (Radio Telef's Éireann) - a name that was legally adopted in 1966.

5. The Teilifis Scoile series ran from 1964 to 1975 , covering a wide variety of curriculum subjects at post-primary level.

6. Quotations from letters held in the RTÉ archives to members of the Educational Advisory Committee.

7. The Broadcasting Review Committee recounted that 33 hours, or 1.4 per cent of total programming time, was given to adult education in 1972-3. All of these programmes were imported in that year, from a budget of $£ 5,000$ allocated to adult education annually by RTÉ (1974: 108).

8. For example, the educational schedule on RTÉ television in 1985-6 consisted of cookery, historical, arts and crafts, health, and foreign language programming (Source: RTÉ Educational Schedules).

9. The Audio Visual Centre (based in University College Dublin) was later established as an independent multi-media company, AV Edge.

\section{References}

Bell, D. 1984 'Proclaiming the Republic: broadcasting policy and the corporate state in Ireland' in Kuhn, R. (ed.) Broadcasting and Politics in Western Europe. London: Frank Cass.

Bell, D. 1995 'Communications, Corporatism, and Dependent Development in Ireland', Journal of Communication 45 (4): 70-88.

Briggs, A. 1965 The History of Broadcasting in the United Kingdom, Vol. II: The Golden Age of the Wireless. London: Oxford University Press.

Broadcasting Review Committee 1974 Report of the Broadcasting Review Committee. Dublin: Stationery Office

Browne, N. 1986 Against the Tide. Dublin: Gill \& Macmillan.

Cathcart, R. 1984 'Broadcasting: the early decades', in Farrell, B. (ed.) Communications and Community in Ireland. Dublin: Mercier.

Chubb, B. 1982 The Government and Politics of Ireland. 2nd ed., London: Longman.

Clancy, P., S. Drudy, K. Lynch, and L. O'Dowd (eds) 1995 Irish Society: Sociological Perspectives. 2nd ed., Dublin: Institute of Public Administration.

Clarke, P. 1986 Dublin Calling: 2FM and the birth of Irish radio. Dublin: RTÉ. 
Dahlgren, P. 1995 Television and the Public Sphere: Citizenship, Democracy and the Media. London: Sage.

Department of Arts, Culture and the Gaeltacht 1995 Green Paper on Broadcasting: Active or Passive? Broadcasting in the Future Tense. Dublin: Stationery Office.

Doak, R. 1998 '(De)constructing Irishness in the 1990s: The Gaelic Athletic Association and cultural nationalist discourse reconsidered', Irish Journal of Sociology 8: 25-48.

Doolan, L., J. Dowling and B. Quinn 1969 Sit Down and Be Counted: the Cultural Evolution of a Television Station. Dublin: Wellington.

Fisher, D. 1978 Broadcasting in Ireland. London: Routledge and Kegan Paul.

Garnham, N. 1993 'The Media and the Public Sphere', in Calhoun, C. (ed.) Habermas and the Public Sphere. Cambridge, MA: MIT Press.

Gorham, M. 1967 Forty Years of Irish Broadcasting. Dublin: Talbot.

Groombridge, B. 1983 'Adult Education and the Education of Adults' in Tight, M. (ed.) Education for Adults: Adult Learning and Education. London: Croom Helm.

Habermas, J. 1987 The Theory of Communicative Action, Volume 2: Lifeworld and System. Cambridge: Polity.

Horgan, J. 2001 The Irish Media: A Critical History since 1922. London: Routledge.

Hourigan, N. 1998 'Framing Process and the Celtic Television Campaign', Irish Journal of Sociology 8: 49-70.

Höyrinen-Alestalo, M. 2001 'Is Knowledge-based Society a Relevant Strategy for Civil Society?', Current Sociology 49 (4): 203-18.

Hughes, C and Tight, M. 1995 'The Myth of the Learning Society', British Journal of Educational Studies 43 (3): 290-304.

Inglis, T. 1997 'Empowerment and Emancipation', Adult Education Quarterly 48 (1): 3-17.

Jonathan, R. 1990 'State Education Service or Prisoner's Dilemma: the 'hidden hand' as source of education policy', Educational Philosophy and Practice 22 (1): 16-24.

Keane, J. 1991 The Media and Democracy. Cambridge: Polity.

Kirby, P., L. Gibbons and M. Cronin (eds) 2002 Reinventing Ireland: culture, society and the global economy. London: Pluto.

Lee, J. 1997 'Democracy and public service broadcasting in Ireland' in Kiberd, D. (ed.) Media in Ireland: The Search for Diversity. Dublin: Open Air.

MacMahon, J. 1997 'Educational Broadcasting: live and interactive', in EBU Diffusion: Quarterly Journal of the European Broadcasting Union, Winter.

McQuail, D. 1992 Media Performance: Mass Communication and Public Interest. London: Sage.

McQuail, D. and Siune, K. 1986 New Media Politics: Comparative Perspectives in Western Europe. London: Sage.

Milner, H. 2002 Civic Literacy: how informed citizens make democracy work. London: Tufts University, University Press of New England.

O'Broin, L. 1986 Just Like Yesterday: An Autobiography. Dublin: Gill \& Macmillan.

Ó Riágain, P. and M. Ó Gliasáin 1994 National Surveys on Languages 1993: preliminary report. Dublin: RTE

Putnam, R. D. 2000 Bowling Alone: the Collapse and Revival of American Community. New York: Simon \& Schuster.

Roseingrave, T. 1983 '21 years of Irish TV', Irish Broadcasting Review 16: 9-12.

Rowland, W. D. and M. Treacy 1990 'Worldwide Challenges to Public Service Broadcasting', European Journal of Communication 40 (2): 18-37.

RTÉ 1971 A View of Irish Broadcasting. Dublin: RTÉ. 
RTÉ 1975 Educational Media Review Committee Report. Dublin: RTÉ.

RTÉ 1979 Report of the Advisory Committee on Educational Broadcasting. Dublin: RTÉ. RTÉ 1989 Change and Challenge: the future of broadcasting in Ireland. Dublin: RTÉ.

Savage, R. J. 1996 Irish Television: the Political and Social Origins. Cork: Cork University Press.

Scannell, P. and D. Cardiff 1991 A Social History of British Broadcasting, Vol. I, 1922-39. Oxford: Blackwell.

Truetzschler, W. 1991 'Broadcasting Law and Broadcasting Policy in Ireland', Irish Communication Review 1: 6-15.

Tunstall, J. 1993 Television Producers. London: Routledge.

Verstraeten, H. 1996 'The Media and the Transformation of Public Sphere: a contribution for a critical political economy of the public sphere', European Journal of Communication 11 (3): 347-70.

Watson, I. 1996 'The Irish Language and Television: national identity, preservation, restoration and minority rights', British Journal of Sociology 47 (2): 255-74.

Watson, I. 2003 Broadcasting in Irish: Minority Language, Radio, Television and Identity. Dublin: Four Courts Press. 
Copyright of Irish Journal of Sociology is the property of Irish Journal of Sociology and its content may not be copied or emailed to multiple sites or posted to a listserv without the copyright holder's express written permission. However, users may print, download, or email articles for individual use. 